\title{
Proliferative effect of the aqueous extract of Hyptis pectinata on liver regeneration after partial hepatectomy in rats $^{1}$
}

\author{
Efeito do extrato aquoso da Hyptis pectinata na regeneração \\ hepática após hepatectomia parcial em ratos
}

\author{
Gustavo Barreto Melo², Renata Lemos Silva², Valdinaldo Aragão Melo ${ }^{3}$, Ângelo Roberto Antoniolli ${ }^{4}$, Paulo Roberto \\ Teixeira Michellone ${ }^{5}$, Sérgio Zucoloto ${ }^{6}$, Maria Eliza Jordani de Souza ${ }^{7}$, Maria Cecília Jordani Gomes ${ }^{7}$, Rodrigo Borges \\ Correia $^{8}$, Orlando de Castro-e-Silva ${ }^{9}$
}

1. Study performed in the Laboratory of Biochemistry of Liver Transplantation Unit of Division of Gastroenterology of the Department of Surgery and Anatomy of Ribeirão Preto Faculty of Medicine-University of São Paulo (FMRP - USP), Brazil.

2. Graduate student of Federal University of Sergipe, Brazil.

3. Associate Professor of the Department of Medicine, Federal University of Sergipe, Brazil.

4. Associate Professor of the Department of Physiology, Federal University of Sergipe, Brazil.

5. Associate Professor of the Marília Faculty of Medicine (FAMEMA), São Paulo, Brazil.

6. Full Professor of the Department of Pathology, (FMRP-USP), Brazil.

7. Biochemist of Laboratory of Biochemistry of Liver Transplantation Unit of the Departament of Surgery and Anatomy, (FMRP - USP), Brazil.

8. Fellow PhD degree, Assistant of Division of Gastroenterology of the Department of Surgery and Anatomy, (FMRP-USP), Brazil.

9. Full Professor and Head of Division of Gastroenterology of the Department of Surgery and Anatomy, (FMRP-USP), Brazil.

\begin{abstract}
Purpose: This study was carried out to assess the effects of the aqueous extract of Hyptis pectinata leaves on liver regeneration and on serum enzymes (AST, ALT and $\gamma$-GT) after 67\% partial hepatectomy in rats. Methods: AST, ALT and $\gamma$-GT, were determined by conventional procedures using a spectrophotometer (Model E2250-CELM). Liver regeneration was evaluated by immunohistochemical staining for proliferating cell nuclear antigen (PCNA). Results: Oral pretreatment during 4 days at $100 \mathrm{mg} / \mathrm{kg}$ increased liver regeneration index. At $200 \mathrm{mg} / \mathrm{kg}$, AST level was statistically decreased in comparison to the group submited to distilled water administration. The other enzymes assessed disclosed no difference when all groups were compared. Conclusion: The present study shows that the aqueous extract of Hyptis pectinata leaves contains some biological active principles that stimulate liver regeneration at $100 \mathrm{mg} / \mathrm{kg}$ and cause slight hepatic protection at $200 \mathrm{mg} / \mathrm{kg}$.
\end{abstract}

Key words: Liver Regeneration. Partial Hepatectomy. Hyptis pectinata. Plant.

\section{RESUMO}

Objetivo: Este estudo foi realizado com o objetivo de verificar o efeito do extrato aquoso da Hyptis pectinata na regeneração hepática bem como nos níveis das enzimas séricas (AST, ALT e $\gamma$-GT) após hepatectomia parcial de $67 \%$ em ratos. Métodos: AST, ALT e $\gamma$-GT, foram determinadas pelo método cinético utilizando um espectrofotômetro (Modelo E2250CELM). A regeneração hepática foi avaliada por imunohistoquímica (PCNA). Resultados: O pré-tratamento oral de $100 \mathrm{mg} /$ $\mathrm{kg}$ foi realizado durante 4 dias e causou aumento na regeneração hepática O pré-tratamento oral com $200 \mathrm{mg} / \mathrm{kg} \mathrm{diminuiu}$ significativamente os níveis de AST quando comparado com o grupo submetido ao pré-tratamento com água destilada. As demais enzimas avaliadas não apresentaram diferenças quando comparadas entre os grupos estudados. Conclusão: $O$ presente estudo mostra que o extrato aquoso da Hyptis pectinata, numa concentração de $100 \mathrm{mg} / \mathrm{kg}$ possui alguma atividade biológica estimulando a regeneração hepática e causando também um leve efeito hepatoprotetor numa concentração de $200 \mathrm{mg} / \mathrm{kg}$.

Descritores: Regeneração Hepática. Hepatectomia Parcial. Hyptis pectinata. Planta. 


\section{Introduction}

Hyptis pectinata (L.) Poit (Lamiaceae), popularly known in Brazil as "sambacaitá" or "canudinho", is a herbaceous plant with opposing crossed, whole and aromatic leaves. Its flowers are small, clustered into axillary inflorescences, hermaphrodite, pentamer, strongly zygomorphous and bilabiate. It is popularly used to treat rhinopharyngitis, nasal congestion, certain skin diseases, gastric disorders, fever and bacterial infections ${ }^{1,2}$. In the state of Sergipe, it has been recommended for the treatment of inflammation, pain, cancer, bacterial infections and wound healing ${ }^{3}$. In experimental studies it has been disclosed that the aqueous extract of Hyptis pectinata leaves protects the liver function ${ }^{4}$ and has antinociceptive and antiedematogenic effects ${ }^{3}$. The essential oil of the plant contains 33 compounds ${ }^{2}$. Monoterpenes are the most common $(95,8 \%)$. The main constituents are $p$-cymene, thymol and â-terpinene. Together, they correspond to $68 \%$ of the total. The presence of thymol is considered the main factor for the antiseptic property of this plant. Considering that there are no studies defining the effects of this plant on liver, this research aimed at assessing the effects of Hyptis pectinata leaves on liver regeneration after $67 \%$ partial hepatectomy in rats.

\section{Methods}

- Plant material and preparation of the aqueous extract - Hyptis pectinata leaves (identified by Dr C. Dias Silva Jr.; voucher no. ASE 2626, deposited in the Department of Biology of Universidade Federal de Sergipe) were collected outside the blossoming period from the Live Pharmacy of Aracaju, Brazil. The leaves were dried in an oven with air renewal and circulation (model MA-037) at $37^{\circ} \mathrm{C}$ until complete dehydration. Dried Hyptis pectinata leaves were triturated in a blender until a finely granulated powder was obtained. The extract was got from this powder ( $100 \mathrm{~g})$ by adding distilled water $(3: 10 \mathrm{w} / \mathrm{v})$ under constant shaking for $4 \mathrm{~h}$ at $35^{\circ} \mathrm{C}$, followed by filtration ( $\mathrm{pH}$ 6.0). The filtrate was lyophilized (aqueous extract) and stored at $5^{\circ} \mathrm{C}$, yielding $16.2 \mathrm{~g}$ (16.2\%) of lyophilized active material. At the time of use, the extract was resuspended in distilled water at the desired concentrations.

- Animals - The study was carried out on 22 male Wistar albino rats (180 to $230 \mathrm{~g}$ ). They were fed with a standard pellet diet and water ad libitum. All animals were randomly assigned to 4 groups, which consisted of 5 or 7 rats each. During four days, animals from Control, PH100, PH200 and PH400 groups underwent partial hepatectomy and oral administration of distilled water, 100,200 and $400 \mathrm{mg} / \mathrm{kg}$ of the aqueous extract of Hyptis pectinata, respectively. On the fourth day of water and plant extract administration (once daily), partial hepatectomy was performed.

- Surgical procedure - All operations were performed under ether anesthesia. They always happened at the same time in order to avoid the influence of the changes of circadian cycle. The median and left lateral lobes of the liver (corresponding to $67 \%$ of the organ) were excised ${ }^{5}$. After surgery, the rats were on a normal diet for the whole experimental period. Twenty four hours later, they underwent a new operation to remove the remaining liver. Then, they were sacrificed.

- Serum enzymes - Blood samples $(4 \mathrm{ml})$ were placed in container without previous anticoagulant treatment. Aspartate aminotransferase, alanine aminotransferase and gamma-glutamyl transpeptidase activities in serum (AST, ALT and $\gamma$-GT, respectively) were determined by conventional procedures using a commercial spectrophotometer (Model E2250-CELM).

- Liver regeneration analysis - Liver regeneration was evaluated by immunohistochemical staining for proliferating cell nuclear antigen (PCNA) using monoclonal primary anti-PCNA antibody (PC-10; DAKO A/S, Glostrup, Denmark) on formalin-fixed and paraffinembedded liver tissues ${ }^{12,14}$. Sections were cut at $4 \mu \mathrm{m}$, mounted on poly-L-lysine-coated glass slides, deparaffinized, rehydrated in an increasing alcohol series, placed in PBS, and treated with $2 \%$ hydrogen peroxide in methanol for $15 \mathrm{~min}$ to block endogenous peroxidase activity. Nonspecific protein binding was blocked by preincubation with 5\% normal horse serum diluted in PBS for $30 \mathrm{~min}$. This was followed by incubation with PC-10 monoclonal primary antibody, diluted 1:40 in PBS for 120 $\min$ at $25^{\circ} \mathrm{C}$. The sections were then incubated for $35 \mathrm{~min}$ with a biotinylated horse antimouse immunoglobulin. The reaction product was detected with an avidin-biotinperoxidase complex and diaminobenzidine was used as a chromogen substrate. Positive and negative controls were used to assess and control the staining procedure. Sections were examined blindly at high power (400X), and 20 fields were chosen at random. Nuclear labeling indices for PCNA (positive nuclei/total number of counted nuclei) were determined by evaluation of at least 1,000 hepatocyte nuclei.

- Statistical analysis of data - The results were reported as means and standard error of mean (SEM). Mann-Whitney's test was used to compare the results between the groups, with the level of significance set to $5 \%$.

\section{Results}

As presented in Figure 1, liver regeneration index was increased in PH100 Group in comparison to Control Group ( $\mathrm{p}<0.05)$. Data from PH200 and PH400 Groups did not disclose statistically significant difference when compared to Control Group. Concerning with serum levels of $\gamma$-GT and ALT, there was no statistical significance when all groups were compared. On the other hand, AST level was statistically decreased in PH200 Group in comparison to Control Group $(\mathrm{p}<0.05)$. The other data were not statistically significant (Table 1). 
TABLE 1 - Data showed as means and standard error of mean of serum ALT, AST and $\gamma$-GT levels in the absence and in the presence of different concentrations of the aqueous extract of Hyptis pectinata $(100,200 \mathrm{and} 400 \mathrm{mg} / \mathrm{kg})$.

\begin{tabular}{lcclll}
\hline Group & Dose $(\mathrm{mg} / \mathrm{kg})$ & $n$ & ALT $(\mathrm{IU} / \mathrm{l})$ & AST $(\mathrm{IU} / \mathrm{l})$ & $\gamma$-GT \\
\hline Control & - & 5 & $324.6 \pm 105.7$ & $582 \pm 176.8$ & $26.4 \pm 1.8$ \\
PH100 & 100 & 5 & $394 \pm 51.6$ & $628.5 \pm 94.4$ & $29.8 \pm 3.9$ \\
PH200 & 200 & 7 & $236.7 \pm 44.8$ & $335.5 \pm 96.9 *$ & $28.7 \pm 7$ \\
PH400 & 400 & 5 & $422 \pm 111.8$ & $530.8 \pm 104.4$ & $36.6 \pm 17.1$ \\
\hline
\end{tabular}

$* \mathrm{p}<0.05$ vs. Control

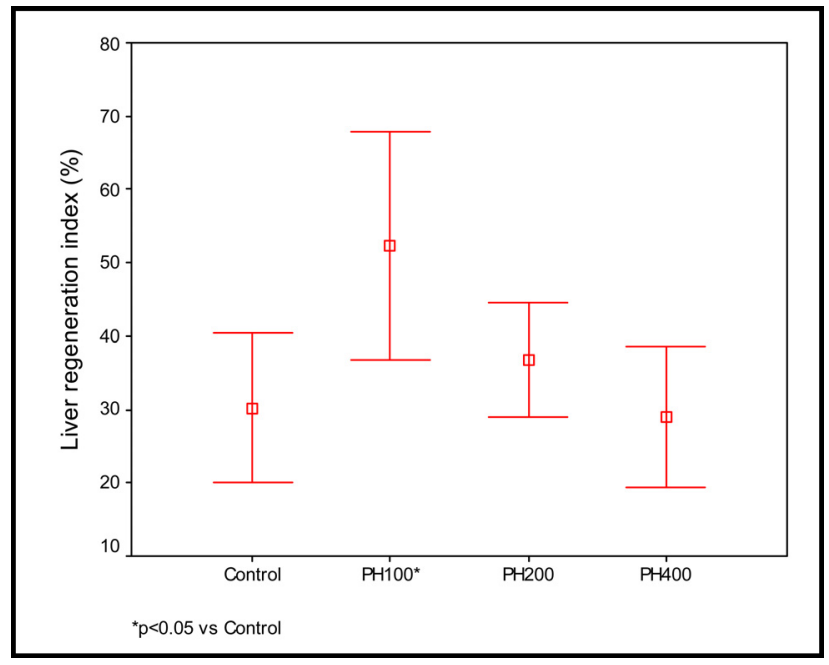

FIGURE 1 - Data presented as means and standard error of mean of liver regeneration index (\%) in the absence and in the presence of different concentrations of the aqueous extract of Hyptis pectinata $(100,200$ and $400 \mathrm{mg} / \mathrm{kg})$.

\section{Discussion}

According to Stephenson ${ }^{6}$, all drugs exert a dosedependent effect on their targets. However, this process depends on the amount of available receptors and the physical and chemical properties of the substances. This theory is applied to pharmacology. On the other hand, phytotherapy is not fully understood. It is possible that, at some concentrations, certain compounds of the plant extract could act in synergism and cause a significant effect. At lower or higher concentrations, these compounds could be antagonyzed by different ones. In a recent work performed by our group, it was verified an antiproliferative activity of copaiba oleoresin on liver regeneration in rats ${ }^{7}$. In the present study, liver regeneration was not stimulated at 200 and $400 \mathrm{mg} / \mathrm{kg}$. This might be explained by hepatocellular membrane receptors saturation or a possible blockage of some stage of the metabolic reaction. It may lead to an uncoupled mitochondrial function which is able to cause relative decrease in liver regeneration and function, as verified in the copaiba oleoresin study ${ }^{7}$. Stimulatory and inhibitory effects are also common in biostimulation by light depending on the dose or wave length ${ }^{8,9}$. This is an important matter whose answer has not yet been fully formulated. The mechanisms previously analyzed are important to understand why liver regeneration index was increased only at $100 \mathrm{mg} / \mathrm{kg}$ and AST levels decreased at 200 $\mathrm{mg} / \mathrm{kg}$. Serum gamma-glutamyl transpeptidase $(\gamma-\mathrm{GT})$ has been widely used as an index of liver dysfunction and marker of alcohol intake. It has a physiological role in counteracting oxidative stress by breaking down extracellular glutathione and making its component amino acids available to the cells. Conditions that increase serum $\gamma$-GT, such as obstructive liver disease, high alcohol consumption, and use of enzymeinducing drugs, lead to increased free radical production and the threat of glutathione depletion ${ }^{10}$. The fact that there was no alteration in $\gamma$-GT values when the plant extract was used means that Hyptis pectinata is not toxic to the rat. The presence of aminotransferases in serum may imply that there has been hepatocellular necrosis ${ }^{11}$. It is usually found that AST and ALT levels are increased after partial hepatectomy. Most likely, this result is caused by traumatic surgical damage to hepatic mass ${ }^{12}$. In this experiment, the plant extract at different concentrations did not induce additional damage to the liver remnant. Inversely, it caused reduction in AST levels at 200 $\mathrm{mg} / \mathrm{kg}$. This means that the compounds of Hyptis pectinata leaves act in synergism to bring about hepatoprotection. In conclusion, our results show, for the first time, that the lyophilized aqueous extract of the leaves of Hyptis pectinata causes improvement on liver regeneration index at $100 \mathrm{mg} / \mathrm{kg}$ and hepatic protection at $200 \mathrm{mg} / \mathrm{kg}$. 


\section{References}

1. Rojas A, Hernandez L, Pereda-Miranda R, Mata R. Screening for antimicrobial activity of crude drug extracts and pure natural products from Mexican medicinal plants. J. Ethnopharmacol. 1992; 35:275-83.

2. Malan K, Pelissier Y, Marion C, Blaise A, Bessiere JM. The essential oil of Hyptis pectinata. Planta Med. 1988;54: 531-2.

3. Bispo MD, Mourão RH, Franzotti EM, Bomfim KB, Arrigoni-Blank MF, Moreno MP, Marchioro M, Antoniolli AR. Antinociceptive and antiedematogenic effects of the aqueous extract of Hyptis pectinata leaves in experimental animals. J Ethnopharmacol. 2001; 76:81-6.

4. Melo GB, Silva RL, Melo VA, Lima SO, Antoniolli AR, Silva PM, Marcassa LG, Bagnato VS, Zucoloto S, Ramalho LNZ, Ramalho FS, Castro e Silva O Jr. Enhancement of liver regeneration by the association of Hyptis pectinata with laser therapy. Dig Dis Sci. 2005; 50: 949-54

5. Higgins GM, Anderson RM. Experimental pathology of the liver: restoration of liver of the white rat following partial surgical removal. Arch Pathol. 1931;12:186-202.

6. Stephenson RP. A modification of receptor theory. $\mathrm{Br} J$ Pharmacol Chemother. 1956;11:379-93.
7. Castro-e-Silva O Jr, Zucoloto S, Ramalho FS, Ramalho LN, Reis JMC, Bastos AAC, Brito MVH. Antiproliferative activity of copaifera duckei oleoresin on liver regeneration in rats. Phytother Res. 2004; 18: 92-4.

8. Castro-e-Silva O Jr, Zucoloto S, Marcassa LG, Marcassa J, Kurachi C, Melo CA, Ramalho FS, Ramalho LNZ, Bagnato VS. Spectral response for enhacement in hepatic regeneration for hepatectomized rats. Lasers Surg Med. 2003;32:50-3.

9. Morimoto Y, Arai T, Kikuchi M, Nakajima S, Nakamura H. Effect of low: intensity argon laser irradiation on mitochondrial respiration. Lasers Surg Med. 1994;15:191-9.

10. Whitfield JB. Gamma glutamyl transferase. Crit Rev Clin Lab Sci. 2001;38:263-355.

11. Dufour DR, Lott JA, Nolte FS, Gretch DR, Koff RS, Seeff LB. Diagnosis and monitoring of hepatic injury. I. Performance characteristics of laboratory tests. Clin Chem. 2000;46:2027-49.

12. Castro e Silva O Jr, Zucoloto S, Menegazzo LAG, Granato RG, Marcassa LG, Bagnato VS. Laser enhancement in hepatic rageneration for partially hepatectomized rats. Lasers Surg Med. 2001;29:73- 7.

\section{Correspondence:}

Orlando de Castro e Silva Jr.

Rua Campos Salles, 809 - $9^{\circ}$ andar. CEP: 14015-110

Centro, Ribeirão Preto - SP - Brazil.

Email: orlando@fmrp.usp.br
Conflict of interest: none Financial source: CNPq and FAPESP

\section{How to cite this article:}

Melo GB, Silva RL, Melo VA, Antoniolli AR, Michellone PRT, Zucoloto S, Souza MEJ, Gomes MCJ, Correia RB, Castro e Silva O. Proliferative effect of the aqueous extract of Hyptis pectinata on liver regeneration after partial hepatectomy in rats. Acta Cir Bras [serial on the Internet] 2006; 21 Suppl 1. Available from URL: http://www.scielo.br/acb 